\title{
The Politics of Privatization and Europeanization in Europe's Periphery: Slovenian Banks and Breweries for Sale?
}

\author{
NICOLE LINDSTROM ${ }^{1}$ and DÓRA PIROSKA ${ }^{2}$ \\ ${ }^{1}$ International Relations and European Studies, Central European University, 1051 Budapest \\ ${ }^{2}$ Institute of Economics, Hungarian Academy of Sciences, 1502 Budapest and Department of \\ Government, The University of Texas at Austin
}

\begin{abstract}
Many theoretical approaches to Europeanization of EU applicant states portray the process as top-down: governing elites in applicant states conform to EU conditions, constituents provide a permissive consensus and all applicant states converge toward a single EU model. Such approaches direct less attention to how Europeanization is a dynamic, contradictory and contestable process. This case study considers how common pressures of Europeanization both constrain and enable domestic politics in particular domestic fields. We focus on two sites of Europeanization in Slovenia: political debates surrounding the restructuring of the Slovenian banking sector and political turmoil over the sale of Slovenian breweries to foreign investors. In both cases, domestic societal actors managed to hinder and, in one case, halt, the full-scale liberalization and privatization of the Slovenian economy. These actors not only appealed to national interests, namely the preservation of Slovenia's gradualist or nationalist-capitalist development path; they also framed these political struggles within a larger European political sphere.
\end{abstract}

KEY WORDS Europeanization, Slovenia, Banking, Privatization, FDI, National interest

\section{Introduction}

'Slovenia: the Sunny Side of the Alps.' This Slovenian tourist bureau slogan seeks to attract potential visitors to this small, often overlooked former-Yugoslav country. Given that not only backpackers, but George W. Bush, have been prone to confusing Slovakia and Slovenia, the government's slogan can be seen as a broader attempt to market this new EU member state to European and global audiences alike. ${ }^{1}$ Slovenia has also been generally overlooked among academic 'travellers' to Central and Eastern Europe (CEE). Whereas most transition and now Europeanization scholars focus on the dual processes of democratization and economic liberalization and Europeanization in Poland, Hungary, and the Czech Republic, they devote relatively little attention to Slovenia. This neglect could be attributed in part to Slovenia's particular historical legacy. As a former republic of the Socialist Federal Republic of Yugoslavia (SFRY), Slovenia experienced socialism quite

E-mail address: lindstromn@ceu.hu

C 2007 the Editors and W. S. Maney \& Son Ltd

DOI: $10.1179 / 102452907 X 181938$ 
differently from Warsaw Pact states and embarked on transition under more favourable starting conditions. Scholars are now devoting increasing attention to Slovenia. Having entered the EU in 2004 as a 'success story', enjoying the highest GDP of any new EU member state (on a par with Greece and Portugal), and now set to be the first new EU member state to adopt the Euro in 2007, the question arises: to what can Slovenia attribute its alleged 'success'?

Slovenia diverged from transition paths taken by other CEE states. Most CEE states followed a strict doctrine of macroeconomic stabilization, market liberalization, and privatization in the early 1990s, following the advice of international financial institutions and Western advisors. After achieving independence in 1991, Slovenian governments followed a less radical path: implementing a floating exchange rate, protecting domestic industries through formal and informal trade barriers, subsidizing 'national champions', and launching a privatization scheme that kept most ownership shares in domestic hands. Unlike in other CEE states that sought a sharp break from previous political regimes, a higher degree of political continuity existed in Slovenia, with former Yugoslav elites remaining in power throughout the 1990s and the corporatist legacy of Yugoslav worker selfmanagement kept largely in tact. Once Slovenia entered formal EU accession negotiations in 1998, it faced the same pressures as other CEE applicant states to eliminate barriers to the free movement of capital and goods and create free market institutions. Examining the formal adoption of EU laws and regulations in Slovenia, one might conclude that Slovenia's gradualist reform path has now been superseded by more liberal EU laws and regulations. Yet a more in-depth examination of the process of Europeanization in Slovenia presents a more complex picture. EU adaptational pressures did not go uncontested. In this paper, we argue that the legacy of particular reform paths continues to shape domestic political struggles over the content and speed of EU conforming liberalizing measures. ${ }^{2}$

To examine this proposition, we investigate domestic political debates over privatization measures in Slovenia. Privatization of state property, especially in highly internationalized sectors, provides an ideal policy area for studying the interactions between the adaptational pressures exercised by the European Union as well as domestic resistance to this pressure. Through two case studies of privatization processes, of banks and breweries, we examine how domestic pressures hindered and, in some cases, blocked full-scale privatization and liberalization of the Slovenian economy. We consider how different groups of domestic societal actors - including economic experts, political parties, social partners, media and the public - contested the Slovenian government's attempt to open these sectors to foreign investment. We suggest that such a 'bottom-up' approach fills important gaps in the Europeanization of CEE literature. The 'top-down' logic of adaptation, compliance, or 'fit/misfit' that dominates the Europeanization literature makes the main problematique how domestic policy makers can most effectively put European policy into practice. Yet this managerial, technocratic, chain of command logic tends to de-politicize studies of Europeanization, whereby problems of politics are limited to issues of administrative efficiency or institutional appropriateness (Mair 2004). By incorporating a broader range of actors in our analysis of Europeanization, we thus seek to contribute a more substantive understanding of the politics of Europeanization in CEE states. Such an analysis seeks to not only provide a more contingent understanding of the processes of Europeanization in new EU members; it also helps us anticipate the potential implications of these ongoing political and economic struggles for patterns of political contestation within the enlarged EU. 


\section{The Slovenian Way: A Gradualist Path to Europe}

Bohle and Greskovits argue that, despite common pressures brought about by global and regional economic integration, we can observe diverse varieties of capitalism among the eight new EU member states of CEE (Bohle and Greskovits 2006). The Baltic states fall on the more radically neo-liberal end of the continuum, Slovenia exhibits a very different neo-corporatist model, and the Visegrad states fall somewhere in between. If we examine one set of indicators - levels of foreign direct investment (FDI) and ownership structures of firms - we can observe significant diversity among varieties of capitalism in CEE states, as well as between new and old EU member states. Slovenia is commonly portrayed as the CEE country least reliant on FDI (Bandelj 2004). This reputation is borne out by FDI indicators. As Table 1 shows, Slovenia's FDI levels as a percentage of GDP consistently ranks the lowest among all CEE states.

This difference between Slovenia and its CEE counterparts is even more dramatic in the banking sector. By 2001, Slovenia was the only post-socialist state to have kept a significant portion of the banking sector in domestic ownership.

If we examine the ownership structure of Slovenian companies listed on the Ljubljana stock exchange in 2003 to that of other CEE and EU-15 countries (Table 2), Slovenia also appears as an outlier. Foreign owners hold only 8 percent of shares in Slovenian firms, compared to an EU average of 29 percent. The Slovenian state holds an average share of 24 percent in the 28 companies listed on the Ljubljana stock exchange, and a stake as high as 30 percent in ten of those companies (OECD 2002). Slovenian households also comprise an above-average percentage of shareholders in Slovenia at 29 percent. Comparing the ownership structure of Slovenia with neighbouring Hungary, we can observe dramatically different outcomes. Among Hungarian-based firms, foreigners hold almost three quarters of all shares and the state less than 10 percent.

Drawing attention to the diversity of outcomes of the simultaneous processes of Europeanization and transition prompts a closer inspection of the types and causes of different paths each state pursued. To explain why Slovenia followed a less radical path of transition one can point to Slovenia's favourable initial starting conditions. Slovenia experienced an initial transition recession and high inflation after gaining independence in

TABLE 1

Foreign Direct Investment in Central and Eastern Europe

\begin{tabular}{llll}
\hline Country & $\begin{array}{l}\text { FDI as } \\
\text { \% of GDP 1995 }\end{array}$ & $\begin{array}{l}\text { FDI as \% of } \\
\text { GDP 2003 }\end{array}$ & $\begin{array}{l}\text { Share of foreign } \\
\text { banks in assets 2001 }\end{array}$ \\
\hline Czech Republic & 14.1 & 48.0 & 90.0 \\
Estonia & 19.3 & 77.6 & 98.9 \\
Latvia & 13.9 & 35.1 & 65.2 \\
Lithuania & 5.7 & 27.2 & 78.2 \\
Hungary & 25.3 & 51.8 & 88.8 \\
Poland & 5.8 & 24.9 & 68.7 \\
Slovakia & 4.2 & 31.5 & 85.5 \\
Slovenia & 9.5 & 20.7 & 20.6 \\
\hline
\end{tabular}

Source: UNCTAD 2004, World Investment Report 2004. 
TABLE 2

Ownership structure of listed Slovenian companies, 2003

\begin{tabular}{lccccc}
\hline Country & Public & Non-financial & Financial & Households & Foreign \\
\hline Slovenia & 18 & 25 & 23 & 29 & 8 \\
Poland & 30 & 2 & 9 & 20 & 39 \\
Hungary & 9 & 7 & 7 & 4 & 73 \\
Lithuania & 0 & 31 & 4 & 12 & 53 \\
Germany & 6 & 45 & 17 & 14 & 18 \\
Norway & 25 & 17 & 16 & 8 & 34 \\
Italy & 10 & 30 & 19 & 27 & 14 \\
Sweden & 9 & 10 & 28 & 13 & 40 \\
Finland & 8 & 9 & 26 & 7 & 74 \\
Denmark & 7 & 19 & 51 & 16 & 26 \\
UK & 0 & 2 & 19 & 15 & 32 \\
Greece & 0 & 25 & 32 & 34 & 22 \\
EU average & 4 & 19 & 16 & 29 \\
\hline Source: & & & 26 & 29 & .
\end{tabular}

Source: The Framework of Economic and Social Reforms for Increasing the Welfare in Slovenia, Slovenian government, 2005.

1991. But this recession period was shorter and less severe than in other CEE states. Slovenia lost important Yugoslav markets with the violent dissolution of SFRY, with Yugoslav republics absorbing 60 percent of Slovenia's total exports. But these losses were partially offset by Slovenian firms' already well established trade links with Western Europe, a legacy of Yugoslavia's liberal trading regime initiated in the 1970s. Moreover, Slovenia inherited a significantly lower debt burden than other CEE states. While the SRFY was heavily indebted, due to massive borrowing in the 1980s, Slovenia negotiated a very favourable debt rehabilitation agreement with the IMF and international lenders after secession (Piroska 2002). Taking on less than 20 percent of the total Yugoslav debt, Slovenia could manage repayment without much difficulty. Slovenian advocates of independence in the 1980s argued that Slovenia was economically disadvantaged within the SFRY by being forced to subsidize the economically underdeveloped republics by large budgetary and foreign currency transfers to Belgrade. Yet, in retrospect, Slovenia fared relatively well in the Federation in many ways, such as amassing the most economically competitive and technologically intensive industries. While Serbia and Bosnia inherited a majority of resource-intensive firms such as steel and heavy industries, e.g. the manufacturer of the Yugo, Slovenia inherited more flexible firms such as the household appliance manufacturer Gorenje, the pharmaceutical firm Kirka, and the technical product distributor Merkur.

Initial starting conditions are undoubtedly a significant factor in shaping Slovenia's transition path. But one must also take into consideration two other factors: political decisions of governing elites and transnational influences. As for the first set of factors, left-leaning coalitions led by the Liberal Democratic Party (LDS) ruled Slovenia almost uninterrupted between 1992 and 2004, with right-leaning coalitions in power for the one-year period after independence and for a short six-month interval in 2000. No 'cleansing' of former Yugoslav socialists occurred in Slovenia. Former socialist party members went on to assume prominent positions in government and industry. The government pursued a strategy that entailed a substantial role for the state in the economic 
transformation and long-run development of the country. The Slovenian Constitution defines Slovenia as a 'welfare state' (Article 2), and contains many elements of Slovenia's corporatist past, such as the rights of workers to make decisions (Article 75) (Lukšič 2001). Slovenia's privatization policy favoured domestic owners, entailing 40 percent of shares transferred to three state-controlled funds, 40 percent to employees and the remaining 20 percent in internal buy-outs. Many 'voucher capitalists' chose to sell their shares back to authorized investment funds, many of which were owned by Slovenian banking and insurance companies. The government's overall reform strategy was supported by an early consensus among employers, trade unions, political parties and economic experts. This consensus among social partners was institutionalized through corporatist bodies such as the National Council, a second parliamentary chamber representing local and functional interests, as well as legally enforced comprehensive bargaining agreements between labour and capital (Petrin 1995).

The second set of factors concerns the role of external transnational actors. In the early stages of transition, international financial institutions were actively involved in shaping transition strategy in post-socialist states. The 'shock therapy' proposed by Jeffrey Sachs and other advisors became the buzzword to capture the similar set of reforms as well as the speed in which they were advised to implement them. Slovenia's voucher privatization policy that favoured domestic owners went against the prevailing IMF wisdom. In 1992, Sachs travelled to Ljubljana to propose an alternative IMF-endorsed plan for privatization. The then deputy prime minister, Jože Mencinger, and other Slovenian economists strongly opposed Sachs' blueprint. Mencinger recalls, 'We listened to them, but didn't follow their advice. Their agenda was based on ideology, not economics. And the US advisors didn't see a difference between Slovenia and Mongolia'. ${ }^{3}$ When the government formally approved the IMF-endorsed plan, Mencinger submitted his resignation in protest. The first elected Prime Minister, Alojz Peterle, from the nationalist-leaning Demos coalition faced a choice: take Sachs' advice and fire Mencinger, or listen to Mencinger and rebuff Sachs (Ganev 2005: 360). Mencinger maintained his position, and the government submitted a privatization policy that diverged from the IMF proposed plan. Mencinger went on to join the Board of Governors of the Slovenian Central Bank, where he pushed a macroeconomic policy agenda that also diverged from IMF advice. The Slovenian Central Bank chose a floating exchange rate in order to protect domestic industries and maintain a low current account deficit. Mencinger remarks that after the Czech financial crisis of 1999, his former IMF adversaries conceded that he might have been right, or 'at least not completely wrong.'

As Slovenian entered formal accession negotiations with the EU in 1998, European actors played an increasingly important role in Slovenia's transformation path. The EU had exerted 'passive' leverage over Slovenia earlier in the 1990s through financial assistant programs such as Phare, association agreements and the political, economic and institutional conditions set out in its 1993 Copenhagen Criteria. One of the earliest and most contentious episodes in Slovenia's path to Europe occurred when the European Commission, at the behest of Italy, forced Slovenia to amend its Constitution, eliminating a clause that prohibited foreigners from buying land, in order to enter EU negotiations (Bandelj 2004: 465-471). The Slovenian government complied, but not without prompting a heated public debate that raised concerns about the threat of EU membership to national interests. Once Slovenia began formal negotiations, the EU's leverage substantially increased. A burgeoning literature on the Europeanization of CEE examines the mechanisms of EU influence and its effects on domestic change (Schimmelfennig and Ulrich 
Sedelmeier 2005). With some important exceptions, a dominant conclusion of this literature is that EU pressures led to increased convergence among CEE states towards a common set of EU laws and norms (exceptions include (Epstein 2006, Raik 2004). This outcome is attributed to the asymmetrical nature of negotiations, where the EU could set the terms and CEE applicant states, willing to do anything to join, complied in full (Grabbe 2003). Other scholars suggest that the kind of organized domestic resistance to EU pressures observed in West European states was virtually absent in East European states due to their unconsolidated party systems, decimated trade unions and weak civil societies (Schimmelfennig et al. 2003; Howard 2002). In sum, the dominant view of EU influence is that it reinforced democratizing and liberalizing processes already underway in CEE states, or set recalcitrant 'illiberal' regimes on a solid political and economic reform path (Vachudova 2005, Kelly 2004).

Through the following two case studies of privatization processes in Slovenia during EU accession negotiations, we seek to examine two dominant claims in the literature: that Europeanization has led to convergence in CEE and has prompted little organized domestic resistance. Slovenia's relatively small share of FDI as percentage of GDP and an ownership structure that left a majority of shares in state or domestic hands diverged significantly from other CEE states. This outcome can be attributed to factors related to Slovenia's transition process: its favourable starting position inherited from Yugoslavia, an initial macroeconomic policy that sought to maintain current account equilibrium or surplus, and a privatization process that thwarted IMF advice and favoured domestic insiders. The question remains: how and to what extent were external pressures exerted during the EU accession process deemed to threaten Slovenia's less radical reform path? Indeed, after entering EU negotiations in 1998 and facing formal pressure to conform to competitiveness conditions outlined in the acquis as well as more informal pressure from the Commission in annual progress reports, the Slovenian government began to dismantle many of the barriers to foreign entry that were kept in force throughout the 1990s. The government passed new legislation that gave equal rights to foreign and domestic owners, launched privatization processes of firms remaining in state ownership, and adopted a coordinated strategy to attract inward FDI (Slovenian Public Relations and Media Office 2000). Yet, by the time Slovenia entered the EU in May 2004, its ownership structure in many sectors had not fundamentally changed, with a majority of capital remaining in domestic hands. We suggest that this outcome can be partially explained by domestic resistance to liberalizing measures, resistance that was embedded in a domestic consensus surrounding the advantages and ultimate success of Slovenia's less radical transition path.

\section{Contesting Bank Privatization}

In 1999, the Slovenian government adopted a Law on Banking that permitted foreign banks to open branches in Slovenia and abolished laws requiring equal domestic and foreign ownership shares in domestic banks. However, by 2001 the government still owned nearly 90 percent of the banking sector. Finally yielding to mounting formal and informal EU pressure, in May 2001, the Slovenian Government finally initiated a privatization plan for Slovenia's two largest banks, Nova Kreditna Banka Maribor (NKBM) and Nova Ljubljanska Banka (NLB) (Slovenia Business Week 2001). The privatization programmes called for the reduction of the state-owned share in the banks from the current 90 percent to 25 percent plus one share, with 65 percent minus one share being sold to a foreign strategic 
investor (Slovenia Business Week 2001). The European Bank for Reconstruction and Development (EBRD) agreed to take over five percent of the shares in each bank in order to boost investor confidence. The government appointed a commission that would independently assess bids, but, at the same time, reserved the right to make final decisions. The bank privatization process signified one of the most dramatic property changes since Slovenia gained independence a decade earlier and spurred considerable public protest. Privatization and majority foreign ownership of the banking sector generated little concern in other CEE countries. In Slovenia, in contrast, a joint media campaign, public protest and political opposition obstructed and, in the case of NRLB, halted the privatization of Slovenia's largest banks.

The European Commission, in its regular reports on Slovenia's progress towards meeting EU accession criteria, repeatedly raised the slow pace of bank privatization as a main concern. The Commission cited this issue as evidence more generally of the 'gradualist approach to structural reforms in Slovenia' (European Commission 2003). In its general evaluation of Slovenia meeting competitiveness criteria in the 2001 report, the Commission cited the May 2001 bank privatization decision as an 'important step forward' in reducing the role of the state in the economy. The Commission reported that while 'restructuring of the banking sector has progressed somewhat,' they cautioned that 'further work remains' (European Commission 2000). More specifically, the Commission warned that the intention of the state to keep a blocking minority share in the banks would diminish the interest of potential key investors. In its 2003 'Comprehensive Monitoring Report on Slovenia's Preparations for Membership', the European Commission concludes: 'Although limited and partial privatization is taken place in the banking sector, the state remains strongly present in this sector while further privatization would promote reform conducive to competitiveness.'(European Commission 2003: 8).

On 16 July 2001, the Finance Minister invited leading financial institutions to express their interest in the banks. The Belgian bank KBC bid to take over 34 percent of NLB shares, with an agreement that it would increase its shares to 49 percent within three years. Concerning NKBM, European Commission's warnings seemed to be vindicated. To the great surprise of Slovenian government officials, who predicted they would receive at least 25 offers for NKBM, only six financial institutions replied to the Ministry's call for a show of interest. Moreover, out of these six offers only three met the minimal requirements to be taken seriously as biding offers: Italian bank Unicredito, Austrian Bank Austria and Activa Group. ${ }^{5}$ Government representatives stated publicly their disappointment that no 'major' bank expressed interest in NKBM. In October 2001, Finance Minister Anton Rop reported that the offers received for the NKBM were too low and would have to be raised during the negotiations phase or otherwise the privatization process would be brought to a halt. NKBM's privatization began to slip behind schedule. The commission supervising the privatization of NKBM asked all bidding institutions to provide additional clarifications and soon after entered talks with all three.

While formal talks proceeded, political conflicts over banking privatization were waged within government and the public sphere. The leading governing party, LDS, strongly supported bank privatization. Slovenian Prime Minister Janez Drnovšek and his ministers were enthusiastic supporters of European integration and were thus eager to dutifully fulfil the EU's formal and informal requirements to gain EU membership. Moreover, Finance Minister Anton Rop hoped to finance the outstanding debt that Slovenia had accumulated to cover the cost of the bank rehabilitation process. However, LDS was 
constrained in its pursuit of bank privatization by coalition and opposition parties. ${ }^{6}$ The United List of Social Democrats (or ZLDS), the former League of Slovenian Communists, advocated that both of the banks should be kept in state hands until domestic investors could purchase a governing share. Although a junior partner in the government, ZDLS had major influence in the Maribor region. The Mayor of Maribor, a ZDLS elected official who holds significant influence as the leader of the second largest city in Slovenia, was an ardent and outspoken opponent of NKBM's privatization. ${ }^{7}$ Marjan Podobnik, vice-president of the coalition Slovenian People's Party (SLS), generally opposed to selling banks to foreigners. ${ }^{8}$ Podobnik advocated a plan that would have split the major banks into smaller regional units (ironically a common tactic of Yugoslav politicians in the past). ${ }^{9}$ At the end of the day, SLS was willing to accept the privatization of NKBM, but opposed the privatization of NLB, Slovenia largest and most important bank.

Prominent economists also weighed in on the debate (Ribnikar and Zajc 2002, Mencinger 2003, Zajc 2002, Moore and Zajc 2000). Advocates of bank privatization put forth several arguments. First, they stressed increased expertise and technology, the possibility of integration into international financial networks, as well as sound financial backing (Damijan and Knell 2005). Moreover, they argued that selling banks to foreigners would help eliminate government interference and 'rent seeking' in the Slovenian economy as a whole. Finally, they argued that foreign capital was necessary to fund the expansion of NLB and NKBM into former Yugoslav markets. Yet economists critical of bank privatization were much more ubiquitous in public debates. The thrust of arguments against foreign ownership of banks centred on two claims. The first line of argument stated that foreign penetration of CEE banking sectors was disproportionately high compared with banking sectors in the EU-15. In Austria and Germany, for example, the total assets of foreign banks were rather small (3.3 percent and 4.3 percent, respectively, in 1997), while the Euro area average in 1997 was 12.7 percent, dramatically lower than the CEE average. To support their argument, they presented data that clearly showed divergence in the banking sectors in terms of foreign presence and state involvement between EU and CEE countries (Figure 3).

Moreover, they attributed the high foreign presence in other CEE countries to insufficient domestic capital, lack of expertise and deficient technological resources shortcomings that Slovenia did not share. The second argument against selling banks concerned the monetary effects that large capital inflow would potentially cause in a small open economy. With many of these economic critics having been actively involved in creating Slovenia's initial macroeconomic polities, they argued that a radical shift in bank ownership structures would adversely affect the exchange rate of the Slovenian currency and subsequently increase the cost of Slovenian exports.

The initiation of formal talks over bank privatization also spurred vociferous public debate. The Maribor based Movement for People sent a public letter to Finance Minister Rop arguing that the sale of NKBM would not be profitable and could have negative effects. The mantra 'Our Bank' became the rallying cry against the sale of both banks. The letter was followed by a well publicized political and media campaign against the sale of NKBM, with the greatest amount of activity in the Maribor region (Slovenia Business Week 2001). Popular arguments against the rapid privatization and sale of banks to foreign investors were threefold. First, keeping banking in domestic hands was deemed crucial to preserve national autonomy. Not only was Slovenia capable of relying on its own resources and capital to build a strong national economy, but selling national assets to foreigners would threaten Slovenian national interests and social cohesion. Second, as Slovenia 


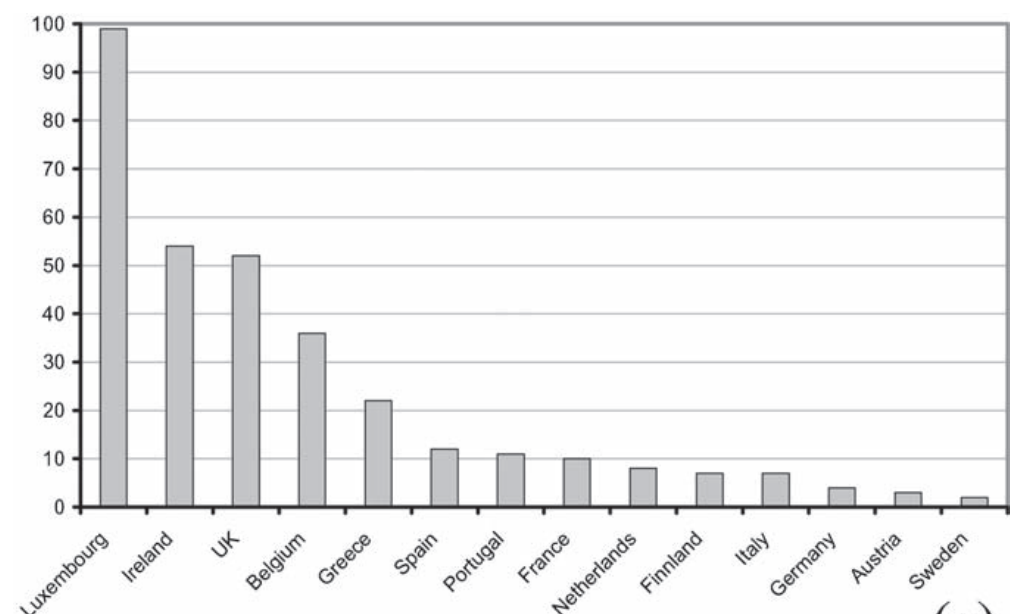

(a)

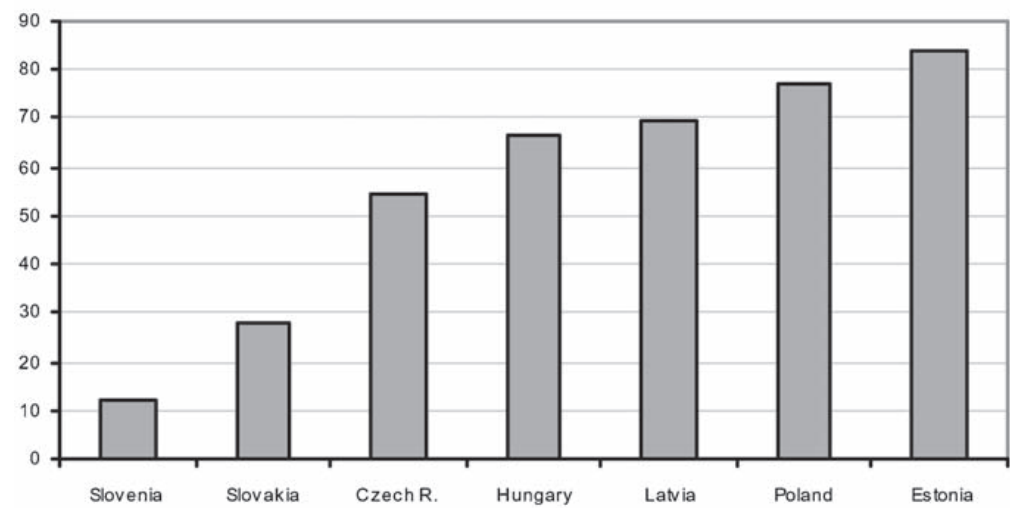

(b)

Fig. 1. Share of foreign bank presence in (a) EU-15 and (b) CEE countries (\% of total assets, 1997). Source: National Bank and Slovenia and EBRD (1998) cited in Moore, D. and Zajc, P. (2000: 10).

prepared to enter the EU as one of the smallest economies, Slovenia faced the threat of being consumed by larger and more affluent EU member states. Further integration into European markets would threaten the largely autonomous and hitherto successful development of the Slovenian economy. Finally, critics argued that increased foreign influence in the banking sector would also bring about a corresponding rise in external political influence in the Slovenian economy. Foreign owners would finance political parties directly or indirectly, thereby gaining influence in national level decision-making, or grant loans only to preferred investors, leaving local businesses and individuals strapped for capital.

Public opinion polls showed that a majority of the public opposed the sale of stateowned banks to foreign investors. In early November 2001, at the height of public debates over the sale of the banks, Delo, the leading Slovenian daily, published a telephone poll that showed an overwhelming majority of respondents (73 percent) responded that the state 
should keep the largest banks in Slovenian hands (Delo Stik 2001). ${ }^{10}$ Asked what they believed the government should do to galvanize larger bidders to invest in state-owned banks in Slovenia, the largest percentage of respondents (43.5 percent) said that the state should retain ownership for a longer period of time. Approximately 35 percent said that the government should sell to Slovenian buyers, depending on their capital, while only 8.6 percent said that the state should sell them to foreigners. In the same survey, however, when asked whether they believed it was feasible for NLB and NKBM to remain in Slovenian ownership in the long run, a majority ( 47.7 percent) reported that they believed there was high possibility that Slovenian buyers would eventually sell the banks, with slightly over 26 percent of respondents remained optimistic that the banks could remain in domestic ownership.

In another survey, respondents were asked whether and how the type of ownership (domestic or foreign) would have an impact on their personal banking decisions. When asked whether they would keep their savings in a bank that came into foreign ownership, 45.1 percent of respondents reported that they would transfer their savings to Slovenian banks, 35.4 would keep their savings in the current bank, and 19.5 were undecided on the issue. Yet when asked what factor they considered most important in their decision to deposit money in a particular bank, only 6.5 percent of respondents said the ownership of the bank was a major factor. When asked to give reasons for the biggest disadvantage of foreign banks over Slovenian ones, a majority of respondents (40 percent) suggested that the main disadvantage of foreign ownership of banks was the political implications - that foreigners would become 'too involved in domestic politics' - rather than more practical concerns such as the cost of services or interest rates.

By the end of March 2002, almost a year after the privatization program was announced, the appointed commission for privatization decided that none of the bidders that submitted biding bids met the necessary conditions (Slovenia Business Week 2002a). After examining all elements of the privatization process, the Ministry of Finance made a decision to temporarily put a halt on the procedure. Representatives of the Bank Austria Creditanstalt expressed surprise about the decision, noting that during negotiations nobody had informed them that their offer was not in line with the privatization conditions. Meanwhile, unofficial information that the sale would not go ahead had been circulating in Slovenian media in the previous weeks before the announcement. According to reports, the final decision to block privatization was taken at the highest level during a meeting between Prime Minister Drnovsek and Finance Minister Rop held on 18 March. However, already on the 14 March President Milan Kučan told the Financial Times that this was not the best time to sell banks to foreign investors, as the supply of banks for sale exceeded demands, and expressed doubts on the need to sell Slovenian banks to foreigners (Slovenia Business Week 2002b).

The European Commission in its 2002 regular overview reported positively that bank privatization had started but 'not without problems,' citing the government's decision to stop the privatization of NKBM and halt NLB privatization in 'the final stages of the process' due to increased 'political resistance' (European Commission 2002: 31) In its general evaluation of Slovenia's progress in meeting economic criteria, the Commission stated that the 'competitiveness of the economy would be supported by speeding up structural reforms.' In particular, the Commission cited 'further privatization in the financial sector' and the 'final liquidation of the Slovenian Development Corporation' as two main goals to be achieved by the close of accession negotiations (European Commission 2002: 23). By the time Slovenia entered the EU in 2004, the Slovenian Development Corporation 
had been liquidated in 2002, with most of the remaining companies in its portfolio transferred to other public and private investment funds in exchange for unused privatization vouchers. Negotiations with KBC over the ownership and management structure of NLB had resulted in an agreement that $\mathrm{KBC}$ would remain a minority shareholder but could appoint four out of nine supervisory board members (with state and proto-state funds appointing four, and one independent). However, when the new government came into power in 2004, they objected to the composition of the supervisory board and KBC subsequently withdrew from the deal. ${ }^{11}$ Meanwhile, a detailed program for the privatization of NKBM was accepted by the government in 2006 and it is still to see its realization (Slovenia Business Week 2006). By the end of 2006 the two largest Slovenian banks remained in majority state ownership.

\section{The Battle over Breweries}

The Slovenian beer market has long been dominated by two popular local brands: Ljubljana-based Union, favoured among Ljubljana connoisseurs, and Maribor-based Laško, the favoured brand outside of the capital. A traveller to Slovenia is hard pressed to find any other beers on offer. Beer is not the only market that is dominated by Slovenian brands. Ordering mineral water in Slovenia, for example, Slovenians simply ask for 'Radenska,' a former Yugoslav brand now owned by Laško. The Slovenian beverage market, like markets in other products, is notoriously hard for foreign firms to penetrate. When Grupo Modelo, a subsidiary of Anheuser-Busch, introduced the Corona brand to Slovenia in 1998, for example, Union responded by introducing a similar brand, Smile, that looked like Corona and was served with its signature lime. Within a year, every café in Ljubljana offered Smile, without a Corona to be found. A Coca Cola marketing representative in charge of Slovenia, Croatia, and Serbia summed up Coca Cola's failure to make inroads in the Slovenian beverage market in socio-cultural terms. In Croatia and Serbia, she observed, most consumers perceive drinking Coke as a sign that they had achieved Western consumer status. In Slovenia, in contrast, drinking the favoured Slovenian-produced (and former Yugoslav brand) Cockta, which is not cheaper, expresses a kind of national patriotism or, somewhat paradoxically, a certain nostalgia for Yugoslav products. ${ }^{12}$

The rivalry between Laško and Union had always involved more than a question of taste in beers; it was perceived as a matter of regional pride. This traditional regional rivalry was tested in November 2001 when the Belgian based brewing company Interbrew entered a bidding war with Pivovarna Laško for controlling shares in Union. Slovenians now united around the perceived threat of a foreign takeover of a beloved national brewery. Interbrew is well established in other parts of Central and Eastern Europe, having purchased local breweries in Bulgaria, the Czech Republic, Hungary, Romania, and elsewhere. Interbrew's entry into other Central European markets raised little public attention. Yet in Slovenia the proposed takeover prompted heated public debate and strong opposition. The so-called 'brewers' war' was framed as a battle between David and Goliath: with a small statemajority owned brewery going against a large EU corporate conglomerate. The takeover battle also tapped in to ongoing debates in Slovenia over whether the Slovenian economy would benefit from the influx of foreign capital. The 'brewer's war' culminated in a protracted legal battle, a parliamentary hearing, the firing of a government privatization fund manager, and a panel debate on brewery privatization broadcast on national Slovenian television (Bandelj 2003). 
The takeover battle between Interbrew and Lasko rested in large part on the actions of two proto-governments funds: the Pension Fund Management (KAD) and the Slovenian Reimbursement Company (SOD). Interbrew acquired its ten percent stake in Union from the KAD in December, thereby gaining 38 percent ownership of the firm. Laško alleged that Interbrew violated the act on takeovers by upping its offer without issuing a new public offer, a claim that was eventually dismissed by the Slovenian Securities Market Agency. Laško already owned just under a quarter of Union shares, and was rapidly buying out small shareholders to assume majority ownership. In 2001, Laško succeeded in obtaining a 12 percent share previously owned by the SOD. The sale turned out to be a one-man move by the SOD director, a Slovenian People's Party appointee. While he claimed it was a sound business decision, he was promptly fired by the SOD supervisory board. His dismissal did not placate Interbrew. In December 2001, Interbrew filed charges with the Ljubljana District Court to prevent Laško from using its 12 percent share acquired by the SOD, arguing that the SOD had single-handedly signed the contract on the sale of SOD shares and had thus abused office. The District Court ruled in Interbrew's favour and temporarily banned Laško from purchasing additional shares. Two months later, however, the High Court overturned the District Court rulings, freeing Laško to wage another takeover battle. At the same time, the Slovenian Securities Market Agency launched proceedings against Laško for violating anti-trust laws, prompted by a complaint filed by Interbrew.

While the battle between Interbrew and Laško was being waged in court, a heated public debate ensued over foreign versus domestic ownership. The Liberal Democratic Party (LDS) majority government supported the sale of Union shares to Interbrew, with Prime Minister Janez Drnovšek pledging his support publicly. However, a multi-party coalition of over 30 members of the Slovenian Parliament, including LDS members, petitioned to convene an emergency parliamentary session of the sale of Union to Interbrew. The campaign, led by SLS and the Slovenian National Party, argued that it was in Slovenia's national interest to keep its best and most competitive companies in Slovenian hands (Finance 2001a, b). Janez Podobnik, a SLS Member of Parliament, stated: 'When we talk about selling Union, we are talking about national interests.'(Finance 2001c) Moreover, they called on the government to dismiss the chairman of the KAD for selling its stake to Interbrew, alleging that Interbrew 'prearranged the deal and put Laško in an unequal position' (Slovenia Business Week 2002a). Borut Korun, leader of the Eurosceptic NGO, the December 23 Movement (named after the date of Slovenian independence), argued that foreign investors come to Slovenia merely for profit and that EU members skilfully use the relative poverty of the countries of the former Eastern bloc to their competitive advantage (Slovenia Business Week 2000b). In an October 2001, public opinion poll, 74 percent of all respondents, when asked whether Union should be domestically or foreign owned, argued that Union should stay in domestic hands (Pavlin 2001).

European officials also weighed in on the debate. Interbrew had repeatedly expressed its concerns about the Union privatization process to the European Commission. ${ }^{13}$ While the Commission could not sanction Slovenia directly, it could appeal to the Copenhagen Criteria on competitiveness and/or resort to shaming. An EU official commented on the disputes in Delo stating that 'foreign direct investment is undoubtedly positive for Slovenia's integration into the European economic arena' (Slovenia Business Week 2000b). Spain's Ambassador to Slovenia remarked that Slovenia must 'find a balance between strengthening its own identity and opening outwards' (Slovenia Business Week 2000b). Prime Minister Drnovsek, having made EU accession his primary political objective in his ten-year reign, was prompted to comment on the battle in a January 2002 press conference. He remarked 
that 'Slovenia's national interest is not protected by domestic ownership. The national interest is job, high-quality products and a high standard of living' (Slovenia Business Week 2000a). He went on to say that the government did not take sides in the battle, stating that: 'through its institutions, the state only wants to assure [sic] that the procedure is transparent and that the rules of the game that we have adopted are observed.'

'David' ultimately prevailed. In 2005, Interbrew withdrew all its lawsuits and complaints against Laško as well as its lawsuit against the Slovenian state and Laško proceeded to purchase Interbrew's 41 percent share, thereby gaining control of 95 percent of Union. The competition office approved the deal and proclaimed that 'the takeover would translate in better and cheaper products for consumers' (Slovenia Business Week 2005). This marked the official end of a three-year battle between Interbrew and Laško for control of Union. The result is that the national pearl, Pivovarna Union, remained in Slovenian ownership. Laško has now secured a virtual monopoly over the Slovenian beer and beverage market (Union Brewery 2006). Moreover, nearly 30 percent of Laško remains in state, or state-controlled funds' hands.

Meanwhile Laško is pursuing an aggressive strategy to expand trade and investment in former Yugoslav markets. In 2000, it bought the Croatian Jadranska brewery in Split, from which it produces and sells the licensed Kaltenburg brand and Laško brands to former Yugoslav markets. Laško's battle with Interbew continued, this time outside Slovenian borders. Since 2004, Laško has fought and ultimately lost bidding wars with Interbrew for control of a spate of privatizations of Serbian and Bosnian breweries. '[Interbrew] can spend more, of course, than we can spend,' says an adviser to Laško's managing director. 'But we know the market . . . the mentality, the language.' Laško's outward foreign direct investment in the former Yugoslav markets reinforces the Slovenian government's overall trade and development strategy, which sees opportunities to capitalize on its close historic ties with former Yugoslavia into a coherent strategic and economic policy. As Slovenia prepares to take over the European Council presidency in 2008, EU policy towards the Western Balkans has emerged as a top EU priority for Slovenia. ${ }^{14}$ Laško has lost its battles with Interbrew without its home field advantage. Yet a testament to Laško's success to date of building a competitive national and regional brand is that one can not only observe Laško and Union brands dominating the Slovenian market. One can also see the famous Laško mascot, a golden Alpine mountain goat, glowing outside pubs throughout the former Yugoslavia.

\section{Conclusion}

We are witnessing today an apparent convergence at the level of the institutional development of CEE states. Indeed, the Slovenian government has complied with all outstanding EU requirements, unilaterally agreeing to privatize the banking sector, establishing necessary market institutions and procedures, and opening the economy more generally towards greater flows of FDI. Yet, by focusing solely on this outcome, scholars fail to consider how the process of Europeanization operates not only through institutional adaptation; Europeanization also involves public contestation over the terms and speed of liberalization. Viewing the dynamics of Europeanization with regards to both processes, and the interactions between the two, allows us to see beyond a general concern of Europeanization scholars, namely to what extent do we observe converging patterns in institutions and structures. It creates room for assessing the nature of the changing politics that 
incorporates a broader range of actors and issues from the domestic and larger European public sphere. Moreover, methodologically it requires us to augment top-down approaches to Europeanization by emphasizing locally bound discursive constructions and political struggles. We do so in this paper via the examination of two 'sites' of Europeanization, the restructuring of the Slovenian banking sector and the recent battle between local and foreign breweries.

The broader political implications of our case study are threefold. First, on the part of the governing parties, there has been a tendency to legitimize their actions as a prerequisite to the EU membership. With this move, governments seek to shift the source of legitimacy from the domestic realm to the external realm and from popular legitimacy to institutional legitimacy. Second, we observe that, along with changing the source of legitimacy, governments engage in double talk with its European private and public partners and with the Slovenian public. In other words, the government interprets its actions according to the exigencies of its intended audience, portraying its motivations to the EU as seeking to conform to competitiveness criteria and promising to domestic audiences to protect the 'national interest'. These two competing trends weaken political accountability of the governments to the public and meanwhile shift power from the public to narrower political circles. Finally, that the issue of privatizing banks became a heated political debate shows that, in the context of the ongoing European integration, the public becomes more sensitive to particular issues. The public resists attempts to discuss privatization solely according to its economic aspects (financial costs and benefits) and understands the issue as a larger question of protecting Slovenian national economic interests and/or preserving the principles of social cohesion. This process can be viewed as attempt on the part of the public to countervail prevailing notions of 'competitiveness', seeking alternatives to a radical free market variety of capitalism, as well as seeking to increase the responsiveness of political leaders.

The question remains: how has Slovenia's less radical variety of capitalism fared now that it has become a full EU member? In 2004, immediately following Slovenia's entry into the EU, a new right-leaning coalition government came into power, ending the nearly uninterrupted twelve-year reign of the LDS. The new government, led by the Slovenian Democratic Party (SDS), made economic reform and a break with gradualist policies a keystone of its election platform. The SDS assembled a team of prominent neo-liberal economists to draft a new economic plan, including Mico Mrkaic (educated in the United States) and Jože Damijan. The reform package included over 70 measures that allegedly comprised a 'new paradigm of development' that would be consistent with the Lisbon 'Partnership for Growth and Jobs'. Measures included tax reform, most controversially the introduction of a flat tax, more flexible labour market regulations, liberalization of the pension and health systems, and the 'transparent withdrawal of the state from the economy' through the privatization of state-owned companies.

Prominent EU and US leaders travelled to Slovenia to pledge their overall support for the economic reform package. In his first visit to Ljubljana in March 2006, European Commission President José Manuel Barroso assessed Slovenia's national economic reform programme as 'promising' (Barroso 2006). Prominent flat tax advocates, such as former Estonian Prime Minister Mart Laar (the architect of Estonia's flat tax policies) and the Hoover Institution's Alvin Rabuska, also lent support to the government's tax reform proposals. ${ }^{15}$ In January 2005, Slovenian Prime Minister Janez Jansa travelled to Estonia where he acknowledged that, although Slovenia and Estonia took very different development paths, they now share the same views. Slovenia is 'facing the second wave of 
reforms, which Estonia has already implemented,' Jansa remarked. 'Estonia's success is due to a large influx of FDI and its simple and transparent tax system.'(TV Slovenija 2005). Slovenian flat tax advocates sought to build on the flat tax movement sweeping through CEE that was initiated in Estonia in the early 1990s and rejuvenated by Slovakia's introduction of the flat tax in 2004. In the first visit of a US president to Slovakia, George W. Bush praised the government's flat tax policies as 'wise' (Tzotzis 2005). While the World Bank named Slovakia the top economic reformer of 2004, Slovenia dropped from 35th in 2002 to 52nd place out of 60 countries in the International Institute for Management Development's 2005 competitiveness survey (EU Business 2005). Upon being appointed head of the Slovenia's newly established Office for Development and Growth in January 2005, Damijan claimed that Slovenia's 'path to Lisbon' should go through Bratislava. 'Slovenia's present development path based on the social market economic models of Germany and France must be reconsidered' Damijan remarked. 'Slovenia should follow the path of some new member states such as Slovakia, Estonia or Latvia that have introduced radical structural reforms for a more competitive economy' (Damijan 2005).

Despite the initial fanfare among reformers around the government's economic package, by 2006, the reform strategy was generally considered dead on arrival. In November 2005, Slovenian labour unions led the biggest public demonstration since Slovenia's independence, with over 40,000 protesters gathering to protest the economic reform package. ${ }^{16}$ The European Trade Union Confederation secretary joined the demonstration, proclaiming that: 'Workers must make sure that their voice for a social Europe is heard' (Gaube 2005). Public opinion polls showed that over 80 percent of the public opposed the introduction of a flat tax, and over 50 percent objected to the reform package in general (CJM 2005: 207). Just three months after being appointed head of the Office for Development and Growth, Damijan resigned in protest in March 2006, allegedly over a disagreement with Finance Minister Andrej Bajuk over the slow privatization of NLB. Damijan remarked to the business daily Finance on his resignation: 'My personal views regarding the withdrawal of the state from the economy are somewhat different from the views of some ministers' (Slovenian Public Relations and Media Office 2006). In September 2006, the government submitted a tax reform proposal to the parliament that maintained a progressive tax rate. In a personal interview, Damijan reflected on the failed economic reforms. $\mathrm{He}$ argued that the flat tax proposal had been a 'game' in that its proponents knew it would not succeed but had hoped that by "proposing the flat tax we could negotiate with the social partners and at least achieve something, like some labour market deregulation. Even if we got five or ten percent of what we wanted, it would have been better than nothing'. ${ }^{17}$ But given that the government and the public are 'socialist in mindset,' according to Damijan, 'to really change this mentality and liberalize the economy will take decades' (Slovenian Public Relations and Media Office 2006). Meanwhile, Jože Mencinger reflects on the failed reforms by saying that the government's strategy, like the Lisbon Agenda on which it was based, with its 'abundance of empty words, newly invented phraseology and concepts, action plans and priorities, and similar claptraps' will go in to the dustbin of history as a 'worthless and harmless document'. ${ }^{18}$

\section{Acknowledgements}

We thank Peter Medica, Dorothee Bohle, Andreas Bieler, Andrew Evans, Boštjan Tolar, Kristina Plavčak, Zlato Šabić, Andrej Kurnik and Darko Tolar for comments and 
criticisms on earlier versions of this paper and to those who agreed to be interviewed for this article. Responsibility for the final outcome is entirely ours.

\section{Notes}

1 In 1999, then Texas governor George W. Bush replied to a Slovak journalist in a press conference: 'the only thing I know about Slovakia is what I learned first-hand from your foreign minister, who came to Texas.' In fact Bush was referring to a recent visit from the then Slovenian Prime Minister Janez Drnovšek. Knight Rider New Service, 22 June 1999.

2 Earlier versions were presented at the International Studies Association and Central and East European International Studies Association's 2003 Budapest Convention of International Studies, 27 June 2003 and at the ESRC Seminars on Europeanization at Queen's University Belfast, 30 March 2004.

3 Personal Interview, Jože Mencinger, Ljlubjana. 13 September 2006.

4 Personal Interview, Jože Mencinger, Ljlubjana. 13 September 2006.

5 Activa Group is an Amsterdam-based private firm that grew out of the Slovenia privatization process. Its founder and major owner, Darko Horvat, is considered one of the only Slovenian privatization tycoons. To bid on NKBM Activa Group formed an international consortium comprising Israel's Ganden Group, Slovenia's Factor Banka and EPIC, a Vienna-based investment bank.

6 With the start of the privatization program controversies ensued between the Prime Minister and the parliament namely over the issue of making final decisions in bank privatization. Janez Jansa, leader of the main opposition Social Democratic Party and former President of the National Assembly, fought for the legislative branch to play the major role. Due to his weakening popularity he did not manage to push through a law in the Slovenian parliament regarding privatization. Thus, in Slovenia, unlike in most CEE countries, no bank privatization law was passed by the parliament. This resulted in the Prime Minister's office being granted greater freedom in terms of planning and executing bank privatization. It also contributed to limiting public transparency of the issue. As decision-making shifted to the executive branch, controversies and competing views continued within and between governing coalition parties that now had to be reconciled outside formal parliamentary channels. Interview with leader of SDP, May 2003.

7 Interview with a prominent financial journalist, May 2003.

8 The Liberal Democrats of Slovenia (LDS) and the Slovenian People's Party (SLS) gained substantial influence over the banks. In 1997, LDS was granted the right to nominate representatives to the supervisory board of NLB and SLS to the NKBM. The conclusion of the bank rehabilitation program was announced once this supervisory body was established. Interview with a member of the Privatization Supervising Committee, May 2003.

9 Interview with member of the Privatization Supervisory Committee, May 2003.

10 The survey included a random selection of 706 respondents.

11 Accounts differ over why the government retreated from the deal. One theory is that the KBC deal threatened Finance Minister Bajuk's plan to merge the largest Slovenian insurance company with NLB to create a financial 'national champion'. Interview with Jože Damijan. Ljubljana. 12 September 2006.

12 Personal interview. Coca Cola Bottling Company Representative, Zagreb, Croatia, 20 May 2001.

13 Personal interview, representative of the European Commission Representation to Slovenia, 12 September 2006.

14 Personal interview, Representation of the European Commission Representation to Slovenia, 12 September 2006.

15 In the May 2006 roundtable organized by the Government Office for Growth, Public Relations and Media Office and the Adriatic Institute for Public Policy, the general aim was to discuss 
'incentives/support for reforms on the one hand and obstacles/opposition to reforms on the other'. The main set of questions posed to all speakers was: 'If reforms are in the general interest, should it not be possible for politicians to build a broader support base for reforms? Should we take the opposition to reforms as given and try to implement them even against serious public opposition, media discontent and protests? How much of the 'reform substance' can we afford to lose in such a process of consensus-building?'

16 The demonstrations also led to increased cooperation among different groups within Slovenia. For instance, the so called 'alternative globalists', comprised of individuals and groups having long organized protests with European groups such as ATTAC and domestic mobilizations, joined with the trade unions in organizing government reforms, marking the first real coordination between these groups. According to one prominent alternative globalization activist, the trade unions were 'initially uncomfortable with our less conventional protest methods', like hooking up a public address system on a boat traveling through Ljubljana down the 'free waters' of the Ljubljianica River. Not without ongoing conflicts over tactics and overall goals, the two groups have continued to cooperate, including organizing workshops in the Balkans on EU accession and social cohesion. Personal interview, Ljubljana, 14 September 2006.

17 Personal interview, 12 September 2006.

18 Personal interview, 12 February 2006.

\section{References}

Bandelj, N. (2003) Particularizing the global: reception of foreign direct investment in Slovenia, Current Sociology, 51(3/4): 377-394.

Bandelj, N. (2004) Negotiating global, regional and national forces: foreign investment in Slovenia, East European Politics and Societies, 18(3): 455-480.

Barroso, J. M. (2006) Address to the Slovenian National Assembly, Visit to Slovenia, Ljubljana, 1 March 2006, SPEECH/06/139, European Commission, Press Release.

Bohle, D. and Greskovits, B. (2007) Neoliberalism, embedded neoliberalism, and neocorporatism: paths towards transnational capitalism in Central-Eastern Europe, West European Politics, forthcoming.

CJM [Center za raziskovanje javnega menga]. (2005) Politbarometer 1/2005, Accessed at: www.cjm.si/ sites/cjm.si/files/File/raziskava_pb/arhiv_pb/pb_2005.pdf. (accessed 9 September 2006)

Delo Stik (2001) 8 November.

Damijan, J. (2005) Slovenija do Lizbone prek Bratislava [Slovenia to Lisbon through Bratislava], Slovenian Press Agency, 25 February.

Damijan, J. and Knell, M. (2005) How important is trade and foreign ownership in closing the technology gap? Evidence from Estonia and Slovenia, Review of World Economics, 141(2): 271-295.

European Commission (2000) Comprehensive Monitoring Report on Slovenia's Preparation for Membership, Brussels: European Commission: 30.

European Commission (2003) Comprehensive Monitoring Report on Slovenia's Preparation for Membership, Brussels: European Commission: 8.

European Commission (2003) Comprehensive Monitoring Report on Slovenia's Preparation for Membership, Brussels: European Commission: 36.

Epstein, R. (2006) Cultivating consensus and creating conflict: international institutions and the (de)politicization of economic policy in postcommunist Europe. Comparative Political Studies, 40(8): 1019-1042.

EU Business (2005) Slovenia set to start wide reform despite lack of support and clear goals, 24 December www.eubusiness.com/archive/Euro/051225030015.4rag0zyf (accessed 9 September 2006)

Finance (2001) France Kangler iz SLS je razklal LDS na dvoje, 5 December. 
Finance (2001) SNS: Izjava za javnost glede prevzema Pivovarne Union, 6 December.

Finance (2001) Podobnik: Pri prodaji Uniona gre za nacionalni interes, 13 December.

Ganev, V. I. (2005) The 'triumph of neoliberalism' reconsidered: critical remarks on ideas centered analyses of political and economic change in post-communism, East European Politics and Societies, 19(3): 343-378.

Gaube, A. (2005) Slovenia: at economic crossroads, Transitions Online, 28 November.

Grabbe, H. (2003) Europeanization goes east: power and uncertainty in the EU accession process, in K. Featherstone and C. Radaelli (eds) The Politics of Europeanization, (Cambridge: Cambridge University Press).

Howard, M. (2002) The Weakness of Civil Society in Post-Communist Europe (Cambridge: Cambridge University Press).

Jacoby, W. (2004) The Enlargement of the European Union and NATO: Ordering from the Menu in Central Europe (Cambridge: Cambridge University Press).

Kelly, J. (2004) Ethnic Politics in Europe: The Power of Norms and Incentives (Princeton: Princeton University Press).

Lukšić, I. (1997) Interest organizations in the field of social partnership, in D. Fink-Hafner and J. Robbins (eds) Making a New Nation: The Formation of Slovenia (London: Ashgate).

Lukšič, I. (2001) Politični system republike Slovenije: Očt [The Political System of the Republic of Slovenia: A Primer] Ljubljana: Znanstveno in publicistièno: 9.

Mair, P. (2004) The europeanization dimension, Journal of European Public Policy, 11(2): 337-348.

Mencinger, J. (2003) Does Foreign Direct Investment Always Enhance Economic Growth, unpublished mimeo.

Mencinger, J. (2006) Privatization in Slovenia, unpublished manuscript.

Moore, D. and Zajc, P. (2000) Implementing Bank Privatization in Slovenia, MOCT-MOST: Economic Policy in Transitional Economies, 10(1): 27-54.

OECD (2002) Foreign Direct Investment in Slovenia: Trends and Prospects OECD Directorate for Financial, Fiscal and Enterprise Affairs.

Pavlin, A. (2001) Interbrew nima podpore javnosti, Finance. 1 October.

Petrin, T. (1995) Industrial Policy Supporting Economic Transition in Central-Eastern Europe: Lessons from Slovenia (Berkeley: University of California Press).

Piroska, D. (2002) Varieties of Debt Management in Central and East European Countries: An Institutional Investigation of International Financial Transactions, Intercultural Management and Communication Department's Working Paper No. 1029 (Copenhagen Business School).

Raik, K. (2004) EU Accession of Central and Eastern European Countries: Democracy and Integration as Conflicting Logics, East European Politics and Societies, 18(4): 567-594.

Ribnikar, I. and Zajc, P. (2002) How to privatize and/or sell business enterprises like banks to foreigners, Unpublished paper.

Schimmelfennig, F. and Sedelmeier, U. (2005) The Europeanization of Central and Eastern Europe (New York: Cornell University Press).

Schimmelfennig, F., Engert, S. and Knobel, H. (2003) Costs, commitment and compliance: the impact of EU conditionality on Latvia, Slovakia and Turkey, Journal of Common Market Studies, 41(3): 498-499.

2 Slovenia Business Week (2001) Bank Privatization Stirs up Heated Debate, (46), 12 November.

Slovenia Business Week (2001) Government Gives Light to NLB and NKBM Privatization Programs, (23), 4 June.

Slovenia Business Week (2002a) None of the Bidders for NKBM Meets the Required Criteria, Commission Says, (12), 25 March.

Slovenia Business Week (2002b) Government Holds the Sale of NKBM, (17), 29 April.

Slovenia Business Week (2005) (20), 16 May.

Slovenia Business Week (2006) (19), 15 May.

Slovenian Public Relations and Media Office (2000) Slovenia Gives Green Light to Foreign Investors www.ivi.si/slovenia/background-information/foreign-investors (accessed: 9 September 2006). 
Slovenian Public Relations and Media Office (2006) Development Minister Resigns After Just Three Months, www.uvi.si/eng/slovenia/publications/slovenia-news/3047/3048 (accessed 9 September 2006)

Tzortzis, A. (2005) Flat-tax movement stirs Europe, The Christian Science Monitor, 8 March, 2005.

TV Slovenia (2005) Ava.rtvslo.si 15 February, 2005.

Union Brewery (2006), http://www.pivo-union.si (accessed 9 September 2006).

Vachudova, M. (2005) Europe Undivided: Democracy, Leverage and Integration after Communism (Oxford: Oxford University Press).

Zajc, P. (2002) Banking sector restructuring: lessons from Slovenia and other Central and Eastern European countries, Unpublished paper. 


\section{Author query}

Paper No: COC 11/2-Lindstrom and Piroska

Issue: $11 / 2$

Author: Nicole Lindstrom and Dóra Piroska

Title: The Politics of Privatization and Europeanization in Europe's Periphery: Slovenian Banks and Breweries for Sale?

1. Author: full ref avail yet?

2. Author: please check title, Slovenia not Slovenian, OK?

3. Author: are there titles for this and next ref? 